\title{
Introduction
}

In the view of the editors and contributors to this volume, and indeed to many modern scholars in a number of disciplines, Thorstein Veblen was a most fascinating and unique American economist. To him also belongs the almost singular distinction of being the author of a classic book that is actually read - albeit, by few of today's economists. Indeed, this lack of influence over today's economics profession is an important anomaly, given his importance in related social sciences such as sociology or marketing. Of course there are intelligible, if indefensible, reasons for this oversight. While the absence of Veblen in today's economics is not the sole subject of the following essays, it may be stated without equivocation that, to the editors and contributors to this book, the neglect of Veblen's work has been to the detriment of American intellectual life, the economics profession, and ultimately to informed discussions of public policy.

The facts of Veblen's early life have often been recounted and for that reason will not be treated here in any detail. Often mentioned is the influence of his upbringing on his later career as a 'non-conformist' scholar and what would today be termed a 'public intellectual'. While each of us undoubtedly has our own personal history that underlies our later outlook and motives in life, in the case of Veblen these speculations too often convey the impression that his life (and thereby) work were simply idiosyncratic to the point that they do not need to be taken seriously. As a consequence the collective, if inadvertent, effect may be to contribute to and indirectly affirm the marginalization of his work both within and without the academy.

Nevertheless for completeness, and in keeping with long-standing practice, let us begin this introduction with a few words concerning Veblen's family background and early education. He was born on 30 July 1857 on a farm in a recently settled area in Wisconsin. His family, like much of his community, was constituted of recent Norwegian immigrants who brought from that nation a strong attachment to the family farm as both a means of earning a living and as the foundation to a broader claim for social status within the community. Veblen, like his older brother Andrew, eschewed the nearby Lutheran college, St Olaf's, in favour of Carleton College, which was further both from home and from the more eastern seaboard in its overall ethos

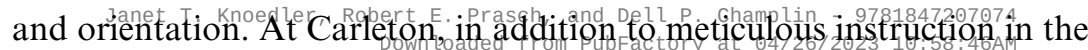


then theologically approved and virtually mandatory Common Sense school of philosophy, Veblen was also exposed to a broadly 'liberal' education that included several courses by a most able and broadly educated young scholar, John Bates Clark. However, according to his most authoritative biographer, Joseph Dorfman, Veblen also had additional, and substantial, intellectual influences. One was his older brother Andrew, with whom he engaged in a study of Old Norse along with some of the sagas and myths written in that language. Additionally, he had the benefit of friendship with a German exile named Pentz who shared his ideas, along with books from his excellent private library. It included, besides Immanuel Kant, some of the greatest social philosophers of the late eighteenth and mid-nineteenth century, including Herbert Spencer, John Stuart Mill, David Hume, JeanJacques Rousseau, Thomas Huxley and others (Dorfman, 1934, p. 30).

But these facts of personal biography are inadequate to a full understanding of Veblen. True, most biographers report that he alienated a fair number of the people in his otherwise close-knit immigrant community. The cause appears to be his quick wit, sarcastic manner of speech and lack of religious orthodoxy. These were supplemented by his apparent indifference to the mores and work ethic of the immigrant Norwegian farmer, but there was more to it. ${ }^{1}$

Veblen came of age in the northern Midwest. This fact is not only indicative of some elements of his personality and his apparent reluctance to ingratiate himself with American intellectuals - most of whom were drawn from eastern protestant families with middle class or professional backgrounds. Rather Veblen was raised in the Midwest at a very particular and interesting time in the history of that region and of the nation as a whole. As a young person from a family that valued intellectual and social engagement Veblen was exposed to the discussions and debates surrounding the political and social movements of the nineteenth century that we now call the Grange movement, and its transformation into the broader political movement that we think of as Populism. But this movement had largely peaked and even begun to subside by the time Veblen came of age as a scholar (Veblen published his first scholarly essay in 1891 and his first book in 1899). With hindsight it is now evident that Populism's political energy had largely dissipated with the end of the deep depression of the mid-1890s, and the end of the long deflation of the post-Civil War era.

Veblen's most productive and important years were those during what we now call the Progressive Era, a period that runs from about 1900 to America's entry into World War I in 1917. By contrast to the most influential speakers and leaders of the Populist movement, Progressives were nonradicals in their politics, middle-class in origin, well-educated, and often

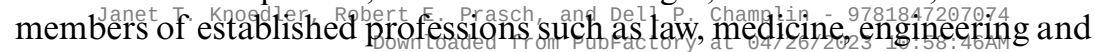


university teaching. To the extent that this fractured movement shared some broad principles, they were that society and social institutions, such as government, business trusts, or urban housing or labour markets, could and should be restructured along the lines that applied science could reveal, and that experts - that is to say, well-educated and civic-minded middle-class professionals such as themselves - should devise, monitor and manage. In short, these principles were anything but the intellectual foundation of a mass political movement. Not surprisingly, even at the height of Progressivism's political influence, the 1912 election, they did not constitute a mass movement. What did exist was a general and widely held outlook or point of view that even an avowed conservative such as Robert Taft felt obliged to adopt.

Thus, to understand Veblen, it must be appreciated that as a youth he came of age in a time and place influenced by the Populist movement, but, intellectually, he came of age during the Progressive era. As a consequence, his thinking shares elements of both, but cannot be located in either. He attended Johns Hopkins, Yale, Cornell and Chicago universities with graduate students and younger faculty who were imbued, or on the cusp of becoming imbued, with the ideals and ethos of Progressivism. But one of Progressivism's attributes was that it was a movement dominated by the young, and many of its leaders and most important figures were a halfgeneration younger than Veblen. Indeed, he was an important intellectual mentor and inspiration to several of them (Fitzpatrick, 1990, ch. 3; Mitchell, 1936 [1964]; White, 1957, ch. 15). By the early 1900s, on the campuses and in the settlement houses of several major cities, this youthful generation of reformers was beginning to devise ideas and social theories that questioned and at times overturned the laissez faire liberalism of the older generation. As an additional influence, many of the leading intellectual figures and activists of the Progressive movement (these were often the same people) looked to Europe, and in particular to Germany for answers. The list of prominent figures who studied political economy in Germany or Zurich is long and includes Florence Kelley, Katharine Davis, Samuel Lindsay, Richard Ely, John Bates Clark, Henry Rogers Seager and W.E.B. DuBois. The exposure of these young and engaged scholars to the intellectual and social milieu of German and Swiss universities was both formative and lasting (Rodgers, 1998, ch. 3; Rutherford, 2000). At a minimum these were places where political economy in the Ricardian tradition, then so dominant in England, was being subjected to severe criticism. The abovenamed scholars and numerous others returned from Germany confirmed in their belief that society needed its economists to deploy the inductive and empirical methods of science to identify problems and devise solutions

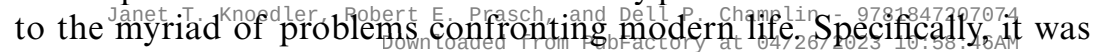


believed that the legal and political institutions that may have been adequate to a largely homogeneous, rural and entrepreneurial economy might be unsuited to one that was modern, multi-ethnic and increasingly urban. This was especially the case for an economy that was becoming increasingly monopolized as a consequence of the tendency of modern manufacturing and transportation technologies to favour large-scale production.

Veblen fits into neither of the above moulds. His writing clearly affirms his disdain for the mass politics of the Populists, especially as they became increasingly nativist and imbued with religious fundamentalism over the first decade of the twentieth century. It is equally evident that he did not subscribe to the ideal of American agrarian life as a fading utopia that had to be recovered and restored. At the same time Veblen did not share the optimism, elitism and eastern Yankee-Protestant outlook that were the undercurrents of so much of Progressive thought and politics (Hofstadter, 1955a).

Yet Veblen's ideas did not appear ex nihilo. Intellectually, it is evident that he drew some inspiration and perspective from the ideas, arguments and moral stances of each of these movements. To restate the assertion made above, Veblen belongs to neither and to both of the most important reformist intellectual and political movements of his lifetime. On the one hand, one can find in Veblen the deep distrust of the motivations of big business - the Captains of Industry, as he called them. One can also find a deep distrust of government, and the view that the courts, legislature and several government agencies were, as a matter of course, beholden to these same Captains of Industry (Veblen, 1904 [1978], 1923 [1997]). In sum, Veblen displayed the tendency to nihilism that was a characteristic theme of Populism. But while this tendency is evident, his politics were also much richer than has previously been supposed, as is evident in the important essay by Sidney Plotkin that appears in this volume.

Yet it is clear that it would be an error to characterize Veblen as a Populist. His last book, Absentee Ownership, makes it plainly evident that he does not share one of the foundational myths of the Populists: that at some point in its recent past America could be characterized as a wonderful, but now eclipsed, agrarian utopia. He finds the English agricultural tradition, as transferred to the United States, to be rife with land speculation, poor husbandry, sharp trading practices and small-time hustling (Veblen, 1923 [1997]). Certainly this disdain for American farming practices was a perspective that was consistent with the views of the Norwegian immigrant farmers of the community within which he was raised. Moreover, a careful sifting of his views on money suggests that they were, for his time, rather orthodox (that one cannot say the same for his views on credit and capital is

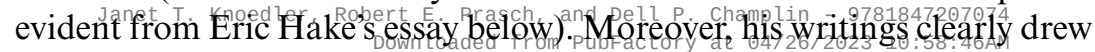


upon the attitude of scientific argument, empiricism, and close analytic methods characteristic of the Progressive thinkers. We also see the footprint of the Progressives in his belief that, if society was ever to be reconstituted upon a workable and non-predatory basis, it would have to be accomplished by a group of more or less disinterested experts imbued with a producerist ethic, such as the engineers.

In short, while Veblen clearly was an American thinker in his methods, outlook, perspectives and examples, he also was and remains unique in the sense that his writings defy classification. One unfortunate consequence was a lack of a school of followers, although over the longer run his work inspired, and continues to inspire, many scholars (Mitchell, 1936 [1964]).

\section{VEBLEN'S CONTRIBUTION}

The economist Joseph Schumpeter once remarked that intellectuals spend their lifetimes working out the prejudices that they developed over their first 25 years. This was, as so many of his greatest pronouncements were, somewhat overstated, but as a generalization it has an important insight. The most obvious explanation is that, as must be admitted, most intellectuals simply do not change their minds as they age. But, for many of our most original thinkers, there is another reason. Of necessity the most daring and original thinkers must begin their work with a hunch, an intuition or a notion. This is almost obvious in the sense that no genuinely original idea can be born, as was alleged of the goddess Venus, in a completely perfected form. It follows that when an idea is indeed original it will often take a great deal of time to work out the many implications, insights and understandings embedded within it, many of which may not be evident at the moment that the new idea is born. This gestation may take an even longer period of time if there is lack of support, or even resistance, to the new ideas or insights in question - which is typically the case in the history of economic thought, art and music.

Such was also the case for the ideas of Thorstein Veblen whose academic career was notoriously unstable. As will be sketched below, it is evident that he developed many of his more important insights fairly early in his scholarly career. This claim can be confirmed by rereading his (in hindsight poorly titled) first published essay on economics 'Some neglected points in the theory of socialism' (1891). That Veblen considered this to be an important essay is evident from the fact that he included it when he gathered together a collection of a few of his many essays and reviews in The Place of Science in Modern Civilisation and Other Essays. In this essay, Veblen

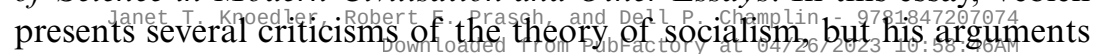


had much broader implications. It was these broader themes, and not his criticisms of socialism, that were to become substantially developed in the course of his later writings.

Veblen begins this essay with a criticism of the famous nineteenth century social philosopher Herbert Spencer. In a paper entitled 'From Freedom to Bondage' (1891), Spencer had reiterated his long-standing argument that the modern legal framework of private property and free contract had made the overwhelming majority of people better off, and for that reason socialists and other critics of capitalist arrangements had no grounds for complaint. Veblen accepted the empirical claim, but disputed the conclusion Spencer drew by making a point that would become a signature of his later work: that people conventionally measure their standard of living and thereby their well-being in relative, not absolute, terms. 'The existing system has not made, and does not tend to make, the industrious poor poorer as measured absolutely in means of livelihood; but it does tend to make them relatively poorer, in their own eyes, as measured in terms of comparative economic importance, and, curious as it may seem at first sight, that is what seems to count' (Veblen, 1891, p. 61).

But determining that it was relative, not absolute, levels of wealth that mattered was only the first step in this refutation. Veblen pointed out that our relative standing was important because our primary concern was for our social status. But this could only be assured through a particular process of tasteful display. Here, then, is another suggestive quotation from this early essay:

It is not enough to possess the talisman of industrial success. In order that it may mend one's good fame efficiently, it is necessary to display it. One does not 'make much of a showing' in the eyes of the large majority of the people whom one meets with, except by unremitting demonstration of ability to pay. That is practically the only means which the average of us have of impressing our respectability on the many to whom we are personally unknown, but whose transient good opinion we would so gladly enjoy. (Veblen, 1891, pp. 62-3).

What, to Veblen, was novel about the 'modern system of industry' was not that it had created the human desire for status or the consequent motive to emulation. Rather it was that 'the system of free competition has accentuated this form of emulation, both by exalting the industrial activity of man above the rank which it held under more primitive forms of social organization, and by in great measure cutting off other forms of emulation from the chance of efficiently ministering to the craving for a good fame' (Veblen, 1891, p. 64).

Another fundamental and, with hindsight, prescient issue that Veblen

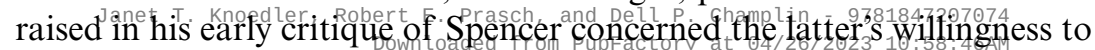


reduce the extensive range of all known social systems into his simple duality of systems of 'status' or 'contract'. Spencer simply ignored the possibility of a myriad of in-between points, along with the extensive possibilities for overlap and interchange between these two (to Spencer exclusive) categories. That Veblen was not exaggerating Spencer's position is clearly evident in the following:

For as fast as the regime of contract is discarded the regime of status is of necessity adopted. As fast as voluntary co-operation is abandoned compulsory co-operation must be substituted. Some kind of organization labour must have; and if it is not that which arises by agreement under free competition, it must be that which is imposed by authority. (Spencer, 1891, p. 13)

To demonstrate the opposing point, that the economic system is always evolving even after competitive markets are the norm, Veblen pointed to the rise of 'natural monopolies'. Here was a well known and, during this era, troubling example of competitive markets demonstrating a tendency to evolve into another form of economic system, one that would certainly bring about a new social form (Veblen, 1891, pp. 69-70). However, this evolution did not imply that a return to a system of 'status' (in Spencer's terminology) was the only logical consequence. Rather, a new manner of social organization, one that Veblen did not attempt to describe, could be a consequence. In sum, Veblen believed that if one took the idea of evolution seriously, then one also had to reject the notion that the then-current system of 'contract' was the end of history.

\section{EVOLUTIONARY ECONOMICS AND INSTITUTIONS}

The theory of evolution, and the multiple efforts that were made to apply it to the social sciences, were important developments in nineteenth and early twentieth century social theory. None of this is to suggest, as innumerable scholars have, that such theorizing had no pernicious effects on ideas and social policy. Some evolutionary ideas, as is well known, were applied in highly irresponsible and often racist ways. But such disastrous applications should not be taken to imply that the notion that societies evolve was simply a false statement. Anyone who reads a history book is struck by both the similarities and the differences between our era and that earlier time. When this occurs, one cannot help but speculate on how things have come to change, or not change, over time. If one begins to think this way, one is soon involved in evolutionary sracial'science. 
In its basic, and perhaps most popular formulations, Social Darwinism held that social life was a struggle between and amongst persons (and sometimes races) from which, on average, only the 'fittest' (or most advanced race) would emerge to take the leading positions in society. In this guise, the political economy of Spencer and William Graham Sumner was not only acceptable, but was rather flattering to the newly rich, their retainers, and their kept intellectuals and apologists. It could now be maintained that the rich held their exalted positions as a consequence of their innate superiority. Moreover failure, while undeniably difficult or even devastating to an individual and those persons dependent upon them, was socially beneficial over the longer term. A presumed consequence of individual failure was that society, on average, would be strengthened as people made of 'better stuff' rose to their 'natural positions' of leadership. This theory did have several weaknesses, however. One cause of tremendous consternation at that time was the observation that immigrants, the poor, and racial minorities all had larger families than their presumptive 'betters': established and prominent families of Anglo-Saxon heritage. Anxious public discussions on the subject of 'race-suicide' were often heard at the turn of the century and these were often the voices of elites. Theodore Roosevelt and Charles Francis Adams were among the many prominent citizens who were publicly voicing their concern for the 'future of the race' (Degler, 1991; Hofstadter, 1955b; O'Flaherty and Shapiro, 2004).

By contrast to the Social Darwinists, Veblen proposed a very different conception of evolutionary social science. He was not particularly interested in the evolution of people as a species - indeed, he often stated that many virtual constants could be found, including our need for self-esteem and the tendency to emulation discussed above - rather, he took the position that an evolutionary economics should take as its primary subject the evolution of institutions (Hodgson, 1998). That this interest was established early on is evident in the subtitle of his first book, The Theory of the Leisure Class: An Economic Study of the Evolution of Institutions (1899a). By 'institutions' Veblen meant much more than the formal or legal institutions of society such as banks, clubs or corporations - rather, he wished to broaden the understanding of institutions by thinking of them as the 'habits of thought' or 'common sense of the community' that constituted the norms and conventions of society.

The evolution of social structure has been a process of natural selection of institutions. The progress which has been and is being made in human institutions and in human character may be set down, broadly, to a natural selection of the fittest habits of thought and to a process of enforced adaptation of individuals

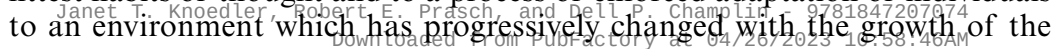


community and with the changing institutions under which men have lived. (Veblen, 1899a, ch. 8; see also Daugert, 1950, ch. 2)

In light of Veblen's understanding that the proper subject of evolution was a study of the evolution of institutions, it is now evident why he thought that Spencer had made a fundamental error when he attempted to build an evolutionary theory of social science while simultaneously presuming that the conventional Anglo-Saxon understanding of property and contract was somehow eternally fixed. It was Veblen's intention to address this error while retaining Spencer's core insight: that social science needed to escape its static conceptions. This latter tendency was an error that Veblen associated with almost the entirety of economic thought from the Physiocrats to the Classical economists, the Marxists and the marginalists, whom he was the first to give the name 'Neoclassical Economists'. That this latter school included his former undergraduate professor, John Bates Clark, was not a consideration that induced him to restrain his criticism (Veblen, 1899b, 1899c, 1900, 1906a, 1906b, 1907).

To Veblen, then, the proper subject of an evolutionary economics was to be institutions. He wished to know what they were, how they functioned, and how they evolved over time. He was interested in how institutions and culture evolved in ways that enabled different groups of persons, Americans of English heritage, the German nation or the Jews of Europe, to succeed or not. His answers were based upon an examination of the economic and social institutions and structures of their societies, and the effects of dayto-day lived experiences on these institutions and the consequences for society. By contrast to the Social Darwinists, he remained substantially less interested in evolutionary theories that theorized about hereditary or genetic effects on the aptitudes or dispositions of different individuals or races.

\section{CONCLUSION}

The essays that follow will review, re-examine and comment upon the subjects that Veblen examined, and consider how his evolutionary theory of the economy and society can continue to inform our understanding of the modern world. Consumption, the legal system, finance and capital, the operations of markets, neoclassical economics, private property, business enterprise, cultural and economic change, the place of science, the good society, and higher education will each and severally be subjects of study. We hope that these essays will shed light on our present system and its likely trends, through a re-examination of a similar system as it was interpreted

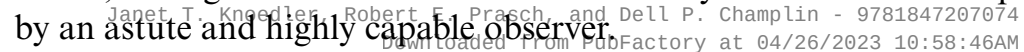




\section{NOTE}

1. Of course, when recounting the impressions of Veblen's neighbours we must be conscious of the tendency of most people, then and today, to consider reading and study to be leisure activities (unless they are pursued for the express and limited purpose of obtaining a specific certification such as a degree). Hence the general impression that Veblen was 'lazy' is consistent with the fact that he devoted a tremendous amount of time to his studies.

\section{REFERENCES}

Daugert, Stanley Matthew (1950), The Philosophy of Thorstein Veblen, New York: King's Crown Press.

Degler, Carl (1991), In Search of Human Nature: The Decline and Revival of Darwinism in American Social Thought, New York: Oxford University Press.

Dorfman, Joseph (1934), Thorstein Veblen and His America, New York: Viking Press.

Fitzpatrick, Ellen (1990), Endless Crusade: Women Social Scientists and Progressive Reform, New York: Oxford University Press.

Hodgson, Geoffrey, M. (1998), 'On the evolution of Thorstein Veblen's evolutionary economics', Cambridge Journal of Economics, 22, 415-31.

Hofstadter, Richard (1955a), The Age of Reform: From Bryan to F.D.R., New York: Vintage.

Hofstadter, Richard (1955b), Social Darwinism in American Thought, rev. edn, Boston: Beacon.

Mitchell, Wesley Clair (1936), 'Introduction', in W.C. Mitchell (ed.) (1964), What Veblen Taught: Selected Writings of Thorstein Veblen, New York: A.M. Kelley.

O'Flaherty, Brendan and Jill Shapiro (2004), 'Apes, essences, and races: what natural scientists believed about human variation, 1700-1900', in David Colander, Robert E. Prasch and Falguni A. Sheth (eds), Race, Liberalism and Economics, Ann Arbor, MI: University of Michigan Press.

Rodgers, Daniel T. (1998), Atlantic Crossings: Social Politics in a Progressive Age, Cambridge, MA: Harvard University Press.

Rutherford, Malcolm (2000), 'Understanding institutional economics, 1918-1929', Journal of the History of Economic Thought, 22(3) (September), 277-308.

Spencer, Herbert (1891), 'From freedom to bondage', Introduction to Thomas MacKay, A Plea for Liberty: An Argument Against Socialism and Socialistic Legislation, New York: D. Appleton and Company.

Veblen, Thorstein (1891), 'Some neglected points in the theory of socialism', Annals of the American Academy of Political and Social Science, 2 (November), 57-74. Veblen, Thorstein (1899a), The Theory of the Leisure Class: An Economic Study of the Evolution of Institutions, New York: Macmillan.

Veblen, Thorstein (1899b), 'The preconceptions of economic science I', Quarterly Journal of Economics (January), 121-50.

Veblen, Thorstein (1899c), 'The preconceptions of economic science II', Quarterly Journal of Economics (July), 396-426.

Veblen, Thorstein (1900) 'The preconceptions of economic science III', Quarterly

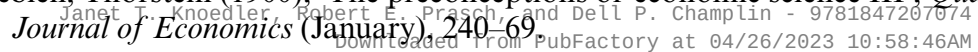


Veblen, Thorstein (1904 [1978]), The Theory of Business Enterprise, New Brunswick, NJ: Transaction Publishers.

Veblen, Thorstein (1906a), 'Professor Clark's economics', Quarterly Journal of Economics (February), 147-95.

Veblen, Thorstein (1906b), 'Socialist economics of Karl Marx and his followers I'. Quarterly Journal of Economics (August), 578-95.

Veblen, Thorstein (1907), 'Socialist economics of Karl Marx and his followers II', Quarterly Journal of Economics (February), 299-322.

Veblen, Thorstein (1923 [1997]), Absentee Ownership: Business Enterprise in Recent Times: The Case of America, New Brunswick, NJ: Transaction Publishers.

White, Morton (1957), Social Thought in America: The Revolt Against Formalism, Boston: Beacon Press. 
Janet T. Knoedler, Robert E. Prasch, and Dell P. Champlin - 9781847207074 Downloaded from PubFactory at $04 / 26 / 2023$ 10:58:46AM 